\title{
The Effect of Preplant
}

\section{Monoammonium Phosphate Fertilizer and Compost on the Growth and Yield of 'Macoun' Apple Trees}

\author{
Renae E. Moran \\ Department of Plant, Soil and Environmental Sciences, University of Maine, \\ PO Box 179, Monmouth, ME 04259
}

\author{
James R. Schupp \\ Pennsylvania State Fruit Research and Extension Center, 290 University \\ Drive, Biglerville, PA 17307
}

Additional index words. phosphorus, fertilizers, fruiting, Malus $\times$ domestica, soil amendments

\begin{abstract}
Macoun'/B.9 apple (Malus $\times$ domestica Borkh.) trees were planted in May 1998 in \pm compost or \pm monoammonium phosphate (MAP) for a total of four preplant treatments: 1) 90 g phosphorus (P) per tree, 2) $128 \mathrm{~kg}$ compost per tree, 3) $90 \mathrm{~g} \mathrm{P}$ and $128 \mathrm{~kg}$ compost per tree, and 4) and an untreated control. MAP did not increase tree growth or yield in any year of the study. Compost increased canopy width into the sixth year after planting, and increased tree height and trunk cross-sectional area (TCA) into the seventh year. Annual yield was increased by compost in the fifth and seventh years, but not fourth or sixth year after planting. Compost increased cumulative yield in the sixth and seventh years.
\end{abstract}

High early yield is associated with good tree growth during the establishment years (Forshey, 1988; Koch et al., 1980; Neilsen and Yorston, 1991). Slow growth reduces yield because trees do not attain a size large enough for cropping until the third or fourth year after planting. This commonly occurs in regions with a short growing season, such as Maine. Cultural practices that encourage rapid tree growth could potentially lead to greater early yield.

Monoammonium phosphate (MAP) added to the planting hole can increase tree vigor and flowering, particularly on replant sites (Bould and Parfitt, 1973; Neilsen et al., 1990; Taylor, 1975; Taylor and Goubran, 1975), but has not been effective in increasing yield unless combined with soil disinfestation (Neilsen and Yorston, 1991) or the addition of organic matter (Nielsen et al., 1994). In Maine, soil incorporation of MAP was ineffective in increasing early tree growth since soil levels were already high (Moran and Schupp, 2003).

Adding organic matter to the planting hole can increase tree growth, flowering and yield, but a sustained increase beyond the third year has not occurred presumably because roots grow out of the treated area (Autio et al., 1991; Neilsen et al., 1991; Peryea and Covey, 1989; Neilsen et al., 1994). Soil incorporation

Received for publication 25 Jan. 2005. Accepted for publication 8 Apr. 2005. Maine Agricultural and Forestry Experiment Station publication number 2800. Mention of a trademark, proprietary product, or vendor does not constitute a guarantee or warranty of the product, nor does it imply approval or disapproval to the exclusion of other products or vendors that may also be suitable. We thank Bruce Hoskins, University of Maine Soil Testing Lab., for leaf and soil analyses. of organic matter in a larger area than the planting hole can extend the increase in tree growth beyond the second year (Moran and Schupp, 2003), but the effect on yield has not been documented. The objective of this study was to determine if preplant soil incorporated MAP or compost can increase yield of apple trees in the first 4 cropping years.

\section{Materials and Methods}

On 1 May 1998, 'Macoun'/B.9 apple trees were planted into one of four preplant soil treatments. The four treatments were \pm MAP and \pm compost, in all combinations. In late April 1998, preplant soil additions were added to strips of killed sod. Compost was applied and leveled to a uniform thickness of $10 \mathrm{~cm}$ over an area of $1.22 \times 1.83 \mathrm{~m}$ for a total of $223 \mathrm{~L}$ of compost per tree. Monoammonium phosphate $(11 \% \mathrm{~N}$ and $24 \% \mathrm{P})$ was broadcast over plots at a rate of $373 \mathrm{~g} /$ tree. All plots were rototilled to a depth of $15 \mathrm{~cm}$ until thoroughly incorporated. In order that each of the four treatments received an equivalent amount of $\mathrm{N}$ (41 g per tree), urea $(46 \% \mathrm{~N})$ was applied at a rate of 89 g per tree to the control and the compost plots not receiving MAP. The compost was made from leaf litter, apple pomace and chicken manure at a ratio of $6: 2: 1$ by volume. Details of composition and analysis of the compost have been previously published (Moran and Schupp, 2003). The soil was a Dixfield fine sandy loam, coarse-loamy, mixed fridgid typic Haplothords. Each plot consisted of three trees with a 'Cortland'/M.26 buffer tree in between each plot, but no buffer row between treatment rows. Trees were planted a spacing of $1.83 \mathrm{~m}$ between trees and $5.50 \mathrm{~m}$ between rows. The site was previously planted to apple trees with the prior orchard being planted in 1956 and removed in 1992. The site was covered by sod from 1992 to 1998 .

At planting, trees were headed to a height of $70 \mathrm{~cm}$ above the ground and attached to a galvanized conduit stake. No additional fertilizer was added the first three years after planting in order to determine the residual effects of compost and MAP. After that, trees were uniformly fertilized as needed according to foliar analysis. In late May of the fourth, sixth and seventh seasons, potassium chloride was added to the soil at a rate of $224 \mathrm{~kg}$ per ha (112 kg.ha ${ }^{-1}$ actual $\left.\mathrm{K}\right)$. Trees were not cropped until the fourth season at which time they were hand thinned to one fruit per cluster. In the subsequent seasons, trees were chemically thinned with follow up hand thinning to one fruit per cluster. Pests and diseases were controlled as needed.

Three soil samples were collected to a depth of $15 \mathrm{~cm}$ from each plot the fourth and sixth years. The three samples from each plot were pooled as one sample for analysis. Samples of 25 midshoot leaves were collected from each plot in late July of the fourth, fifth, and sixth years. Leaves were washed, rinsed three times in distilled water, and dried at $70^{\circ} \mathrm{C}$. Soil was analyzed for $\mathrm{K}, \mathrm{Ca}, \mathrm{Mg}$, and $\mathrm{pH}$. Leaves were analyzed for $\mathrm{N}, \mathrm{P}, \mathrm{K}, \mathrm{Ca}, \mathrm{Mg}, \mathrm{B}, \mathrm{Zn}, \mathrm{Mn}, \mathrm{Cu}$, and Fe. Total $\mathrm{N}$ was determined using the Dumas standard combustion method modified by Sweeney (1989). All other nutrients were measured by dry ashing (Chapman and Pratt, 1961). Solution analysis was by plasma emission. Soil $\mathrm{pH}$ was measured in distilled water using a soil:water ratio of $1: 1$. Nutrients were extracted in neutral ammonium acetate using the modified Morgan extraction procedure (Morgan, 1941).

Beginning in the fourth year, the first cropping year, yield was measured as number and weight of all fruit per tree. Each October, trunk diameter was measured $25 \mathrm{~cm}$ above the graft union. In the fifth, sixth and seventh years, tree height and canopy width at the widest point were also measured. In the fourth season, shoot length was measured on all shoots longer than $10 \mathrm{~cm}$.

The experiment was a randomized-complete-block split-plot design with compost treatment ( \pm compost) and replication in the whole plot, and MAP fertilizer ( \pm MAP) in the subplot. Each treatment was replicated six times. Data were analyzed as repeated measures with SAS software (SAS Institute, 2000) using the MIXED procedure. Means were separated by multiple $t$ tests. Trunk cross-sectional area was log-transformed for analysis because the compost treatment data were positively skewed.

\section{Results}

Preplant MAP had no effect on tree size, mean fruit weight, crop load, yield or cumulative yield in any year of the study (data not shown). However, in the fourth year, total annual shoot growth was slightly decreased by MAP $(P=0.0694)$ with a compost interaction $(P=0.0264)$. Shoot growth was reduced by 
MAP (234 cm) compared to no MAP (316 $\mathrm{cm})$, but only in plots that did not receive compost. In plots with compost, shoot growth did not differ between MAP $(337 \mathrm{~cm})$ and no MAP $(327 \mathrm{~cm})$.

Preplant compost significantly increased tree growth and yield (Table 1) with no interaction between MAP or tree age. Preplant compost increased canopy width the fifth and sixth years, but not the seventh (Fig. 1). Tree height was increased by compost the fifth, sixth and seventh years (data not shown) with a final tree height of $1.89 \mathrm{~m}$ for no compost trees and $2.06 \mathrm{~m}$ for compost trees in the seventh year. Compost resulted in larger trunk cross-sectional area the sixth and seventh years, but not significantly the fourth or fifth years. Compost increased annual yield the fifth and seventh years, but not the fourth or sixth years. Crop load followed a similar pattern as annual yield (data not shown). In the sixth and seventh years, cumulative yield was greater with compost, but not the fifth year. Mean fruit weight was not affected by compost in any year (data not shown).

Momoammonium phosphate had no effect on orchard soil $\mathrm{pH}, \mathrm{Ca}, \mathrm{Mg}$, or $\mathrm{K}$ (data not shown). Soil $\mathrm{pH}, \mathrm{Ca}, \mathrm{Mg}$, and $\mathrm{K}$ were greater with compost the fourth and sixth years, the 2 years in which they were measured (Table 2 ). There was no interaction with MAP or tree age.

Monoammonium phospate and compost had no effect on foliar nutrients the fourth year (data not shown). In the fifth year, preplant MAP increased foliar P to $0.27 \mathrm{mg} \cdot \mathrm{kg}^{-1}$ compared to $0.23 \mathrm{mg} \cdot \mathrm{kg}^{-1}$ without MAP. Monoammonium phosphate did not affect other foliar nutrients. Compost had no effect on levels of foliar nutrients (data not shown).

\section{Discussion}

Preplant soil incorporation of organic matter increased tree growth and yield into the seventh year after planting. Previous studies in which tree growth was increased by organic matter added to the planting hole did not show continued increased in growth beyond the second year (Autio et al., 1991; Nielsen et al., 1994). The longer duration of compost effects could be due to wider soil distribution compared to planting hole amendments, but direct comparisons between planting hole additions and soil incorporation were not made in this study. Annual increments in tree height and canopy spread were not increased by compost in the fifth through the seventh years (data not shown). Increase in TCA from the fifth to the sixth year was greater with compost $(P=0.0262)$, but was not greater in other years. This indicates the larger size of trees in compost plots was largely a result of greater growth in the nonbearing years (Moran and Schupp, 2003).

The increase in tree growth was large enough to impact cumulative yield in years 6 and 7. The yield increase in our study was comparable to increases that occurred with planting hole additions of peat (Neilsen et al., 1994), but was less than the yield increase with soil fumigation (Koch et al., 1980). Whether compost could hasten production was not evaluated in this study since trees were not large enough to be cropped until the fourth year due to slow tree growth that is typical of Maine orchards. The lack of compost effect on yield in the sixth year may be attributed to depletion of soil K. Soil levels fell below optimum levels (Stiles and Reid, 1991) in noncompost plots by the third year and in compost plots by the fourth year. Potassium fertilizer was added to the soil in the fourth and sixth years, but soil levels remained low.
Although foliar $\mathrm{K}$ was in the optimum range, levels decreased over the course of the study, whereas, levels of $\mathrm{N}$ remained steady indicating that $\mathrm{K}$ may have been a limiting factor. Annual yield in the seventh year was lower than in the previous year due to lack of bloom and poor fruit set. This may have resulted from flower bud death, as the winter of 2004 was severely cold with a minimum temperature of $-26.6^{\circ} \mathrm{C}$ and temperatures that dropped below $-20^{\circ} \mathrm{C}$ on 12 separate days.

Monoammonium phosphate fertilization did not increase tree growth or yield. Instead,

Table 1. $P$ values for the main effects of preplant soil-incorporated compost, MAP and tree age from repeated-measures analysis of variance for tree growth and yield in the first four cropping years after planting.

\begin{tabular}{|c|c|c|c|c|}
\hline $\begin{array}{l}\text { Source } \\
\text { of } \\
\text { variation }\end{array}$ & $\begin{array}{c}\text { Canopy } \\
\text { width } \\
(\mathrm{cm})\end{array}$ & $\begin{array}{l}\mathrm{TCA}^{\mathrm{z}} \\
\left(\mathrm{cm}^{2}\right)\end{array}$ & $\begin{array}{c}\text { Yield } \\
\text { (kg/tree) }\end{array}$ & $\begin{array}{c}\text { Cumulative } \\
\text { yield } \\
\text { (kg/tree) }\end{array}$ \\
\hline$\overline{\text { Compost }^{y}}$ & 0.0078 & 0.0031 & 0.0092 & 0.0063 \\
\hline MAP & 0.2807 & 0.2858 & 0.1560 & 0.2705 \\
\hline Tree age & 0.0001 & 0.0001 & 0.0001 & 0.0001 \\
\hline
\end{tabular}

${ }^{2}$ TCA is trunk cross-sectional area.

y Treatment effects on canopy spread and cumulative yield are averaged over all 3 years, and for TCA and yield averaged over all 4 years. Interactions were insignificant.
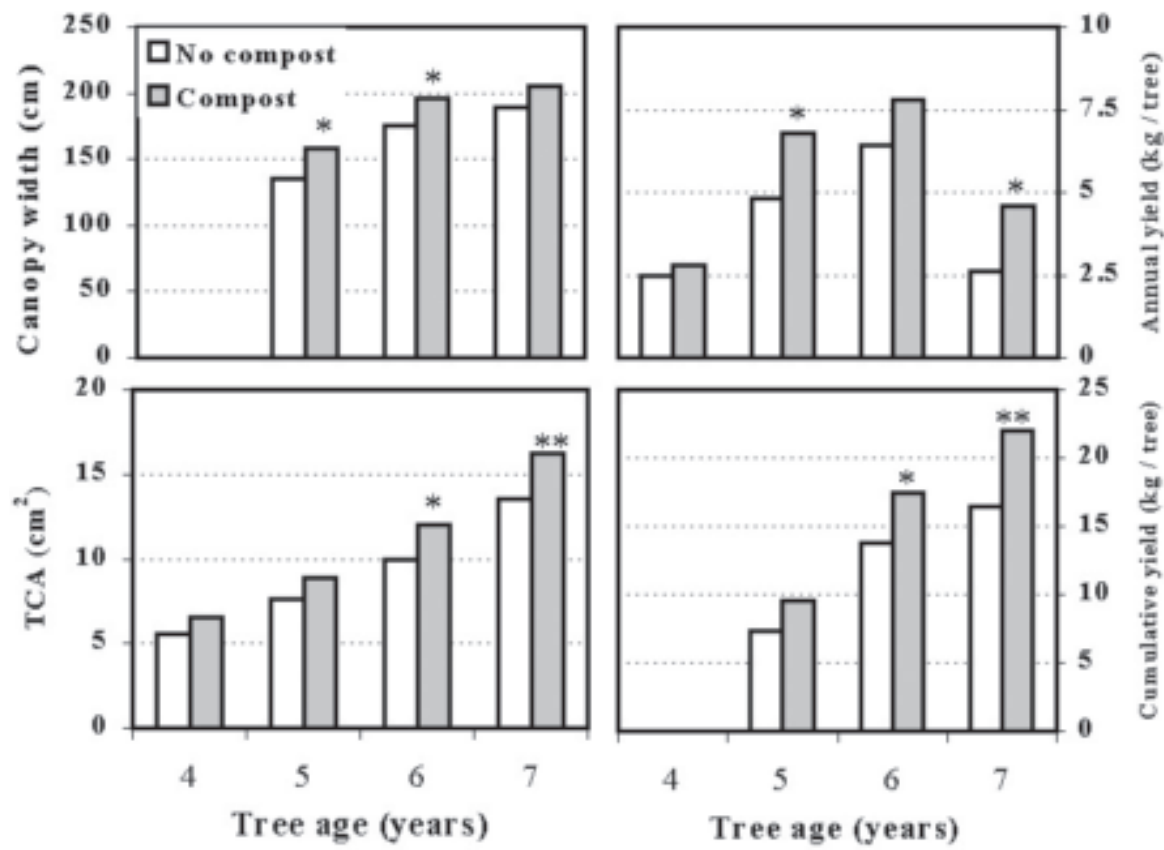

Fig. 1. Tree canopy width, trunk cross-sectional area (TCA), annual yield and cumulative yield of 'Macoun' apple trees $4,5,6$, and 7 years after planting as affected by preplant soil-incorporated compost. ${ }^{*, * *}$ Significant effect of compost within each tree age at $P \leq 0.05$ or 0.01 , respectively.

Table 2. Orchard soil properties in the fourth and sixth years after soil-incorporation of compost and subsequent planting of 'Macoun' apple trees.

\begin{tabular}{|c|c|c|c|c|}
\hline $\begin{array}{l}\text { Compost } \\
\text { (kg/tree) }\end{array}$ & $\mathrm{pH}$ & $\begin{array}{c}\mathrm{K} \\
\left(\mathrm{mg} \cdot \mathrm{kg}^{-1}\right)\end{array}$ & $\begin{array}{c}\mathrm{Mg} \\
\left(\mathrm{mg} \cdot \mathrm{kg}^{-1}\right)\end{array}$ & $\begin{array}{c}\mathrm{Ca} \\
\left(\mathrm{mg} \cdot \mathrm{kg}^{-1}\right)\end{array}$ \\
\hline \multicolumn{5}{|l|}{ Fourth year } \\
\hline 0 & $6.6 b^{z}$ & $56 \mathrm{~b}$ & $121 \mathrm{~b}$ & $1016 \mathrm{~b}$ \\
\hline 128 & $6.9 \mathrm{a}$ & $84 \mathrm{a}$ & $164 \mathrm{a}$ & $1562 \mathrm{a}$ \\
\hline \multicolumn{5}{|l|}{ Sixth year } \\
\hline 0 & $6.7 \mathrm{~b}$ & $71 \mathrm{~b}$ & $134 \mathrm{~b}$ & $1040 \mathrm{~b}$ \\
\hline 128 & $7.1 \mathrm{a}$ & $102 \mathrm{a}$ & $171 \mathrm{a}$ & $1624 \mathrm{a}$ \\
\hline \multicolumn{5}{|c|}{ Analysis of variance $P$ value } \\
\hline Compost & 0.0006 & 0.0003 & 0.0046 & 0.0001 \\
\hline MAP & 0.1402 & 0.1198 & 0.7347 & 0.2676 \\
\hline Tree age & 0.0538 & 0.0073 & 0.4645 & 0.6041 \\
\hline
\end{tabular}

${ }^{\mathrm{z}}$ Means followed by the same letter, within columns and years, are not significantly different $(P \leq 0.05)$ according to $t$ test. Interactions were not significant. 
MAP decreased shoot growth, but not enough to impact yield. Monoammonium phosphate fertilization did not affect the P status of the trees until the fifth year after planting and did not result in an increase in tree growth as it has in other studies (Neilsen and Yorston 1991; Neilsen et al., 1990, 1994). In addition, foliar levels of $\mathrm{P}$ in all treatments were within the optimum range (Stiles and Reid, 1991).

The results of this study indicate that preplant compost incorporation increased tree size and yield into the seventh year after planting. Greater yield with compost was most likely due to improved tree growth in the first few years after planting since compost had little effect on annual increment in trunk or canopy growth in the cropping years. However, the impact on tree size was sustained into the seventh year, and this was enough to continue to impact yield. Trees planted in soil amended with compost filled their space more quickly and were able to support a greater yield.

\section{Literature Cited}

Autio, W.R., D.W. Greene, D.R. Cooley, and J.R. Schupp. 1991. Improving the growth of newly planted apple trees. HortScience 26:840-843.

Bould, C. and R.I. Parfitt. 1973. Leaf analysis as a guide to the nutrition of fruit crops. X. Magnesium and phosphorus sand culture experiments with apple. J. Sci. Food. Agr. 24:175-185.

Chapman, H.D. and P.F. Pratt. 1961. Methods of analysis for soils, plants and waters, p. 60. Univ. Calif.-Berkley, Div. Agr. Sci.

Forshey, C.G. 1988. Care and training of young apple trees. New England Fruit Meetings Proc. 94:98-102.

Koch, B.L., R.L. Covey, and W. Haglund. 1980. Effect of soil fumigation on the early growth and production of 'Delicious' apple trees. J. Amer. Soc. Hort. Sci. 105:887-890.

Moran, R.E. and J.R. Schupp. 2003. Preplant monoammonium phosphate fertilizer and compost affects the growth of newly planted 'Macoun' apple trees. HortScience 38:32-35.

Morgan, M.F. 1941. Chemical soil diagnosis by the universal soil testing system. Conn. Agr. Expt. Sta. Bul. 450.

Neilsen, G.H. and J. Yorston. 1991. Soil disinfection and monoammonium phosphate fertilization increase precocity of apples on replant problem soils. J. Amer. Soc. Hort. Sci. 116:651-654.
Neilsen, G.H., E.J. Hogue, and P. Parchomchuk. 1990. Flowering of apple trees in the second year is increased by first-year P fertilization. HortScience 25:1247-1250.

Neilsen, G.H., J. Beulah, E.J. Hogue, and R.S. Utkhede. 1991. Use of greenhouse seedling bioassays to predict first year growth of apple trees planted in old orchard soil. HortScience 26:1383-1386.

Neilsen, G.H., J. Beulah, E.J. Hogue, and R.S. Utkhede. 1994. Planting-hole amendments modify growth and fruiting of apples on replant sites. HortScience 29:82-84.

Peryea, F.J. and R.P. Covey. 1989. Replant management strategies influence early growth of apple trees in a sand soil. HortScience 24:947-949.

Stiles, W.C. and W.S. Reid. 1991. Orchard nutrition management. Cornell Coop. Ext. Info. Bul. 219.

Sweeney, R.A. 1989. Generic combustion method for determination of crude protein in feeds: Collaborative study. J. Assn. Offic. Anal. Chem. 72:770-774.

Taylor, B.K. 1975. Response of newly planted peach and apple trees to superphosphate. Austral. J. Agr. Res. 26:521-528.

Taylor, B.K. and F.H. Goubran. 1975. The phosphorus nutrition of the apple tree. I. Influence of rate of superphosphate on the performance of young trees. Austral. J. Agr. Res. 26:843-853. 